\title{
Antimicrobial Properties of Stem Bark Extracts of Ximenia Americana
}

\author{
Maikai V.A \\ College of Agriculture and Animal science, Ahmadu Bello University \\ Mando, Kaduna, Nigeria \\ E-mail: ambrosev2003@yahoo.com
}

Maikai B.V.

Department of Public Health and Preventive Medicine, Faculty of Veterinary Medicine

Ahmadu Bello University, Zaria, Nigeria

Kobo P.I

Physiology and Pharmacology Department, Faculty of Veterinary Medicine

Ahmadu Bello University, Zaria. Nigeria

\begin{abstract}
Ximenia americana is endemic in Northern Nigeria, and has been reported to be used in treatment of various types of ailments. In the present study, the antimicrobial properties of the stem bark extracts of Ximenia americana were screened against Escherichia coli, P.aeruginosa, Staphylococcus aureus, P. vulgaris, Candida albicans, B. subtilis using the disc diffusion method. The result revealed the methanolic and water extract showed significant $(\mathrm{P}<0.05)$ broad spectrum activity on the growth of many of the test organisms (E. coli, and P. vulgaris, S.aureus, P. aeruginosa and B. subtilis), while the butanolic extract had little activity. Phytochemical screening revealed the presence of alkaloids, saponins, flavonoids, cardiac glycosides, terpenoids and tannins. The study supports the traditional usage of this plant by herbalist as remedy in curing microbial infections.
\end{abstract}

Keyword: Ximenia americana, Antmicrobial activity, Microoganisms

\section{Introduction}

Traditional medicine is well recognized in Africa and many rural communities rely on the use of ecofriendly and easily available plants in the treatment of a wide variety of ailments. Ximenia americana (Olacaceae) which is also known as "wild olive" in English, is a shrub like plant found in abundance in the West African region. It flowers usually in the second part of the dry season, producing cream - white to greenish yellow flowers. The fruits are green but turn golden-yellow or red. The fruit when eaten is very refreshing and has almond acid taste. In Northern Nigeria, the plant is found in the Savannah areas. It is extensively used among the Hausa/Fulani as herbal remedies in treatment of malaria, leproutic ulcers and skin infections of mixed origin (Ogunleye and Ibitoye, 2003). The leaves have been reported to have antibacterial activity (Ogunleye and Ibitoye, 2003) while leaves have been reported to be used in the treatment of fever, tuberculosis, stiffness, Onchocerciasis tooth decay and wounds (Abonnier, 2004). Abonnier, (2004) have reported the roots to be used in treatment of leprosy, syphilis, dysentery, and wounds. The stem bark has been reported to have antitrypanosmal activity (Maikai et. al., 2008). The stem bark and the leaves also are used in treating headaches and mumps. The present study is aimed at investigating the antimicrobial activity of the stem bark extracts of Ximenia americana .

\section{Materials and methods}

\subsection{Collection of plant Material}

The stem bark of Ximenia americana was collected from Afaka village $35 \mathrm{~km}$ to Kaduna $\left(11^{\circ} 10^{\prime} \mathrm{N}, 7^{\circ} 38^{\prime} \mathrm{E}\right)$ in the month of August 2006 and taken to Department of Biological Sciences herbarium, Ahmadu Bello University Zaria for 
identification the voucher No. 1612 was deposited. The stem bark was dried at room temperature before crushing into powder using an electric blender and then stored in air tight container and kept at $4^{0} \mathrm{c}$ until needed.

\subsection{Solvent extraction}

The powdered material $(200 \mathrm{~g})$ was shaken in $300 \mathrm{ml}$ of acetone: water $(2: 1)$ and further extracted according to Latte (1999) to obtain fractions of different polarities. The extracts included petroleum ether extract (PEE), chloroform extract (CFE), butanol extract (BE), methanol extract (ME) and water extract (WE). Each extract was evaporated to dryness using a hot air oven set at $35^{\circ} \mathrm{C}$. The dried extracts were weighed and then stored in air tight container and kept at $4^{0} \mathrm{c}$ until needed.

\subsection{Phytochemical screening of extracts}

Phytochemical analyses were done using standard procedures (Harborne 1973; Trease and Evans, 1989; Sofowora ,1993).

\subsection{Organisms}

The species of bacterial organisms were Staphylococcus aureus, Pseudomonas aeruginosa, E. coli, bacillus subtilis,Proteus vulgaris and Candida albicans. They were clinical isolates obtained from Ahmadu Bello University Teaching Hospital, Shika Zaria. The cultures of bacteria were maintained on nutrient agar slants at $4^{0} \mathrm{C}$, re -identified by biochemical tests (Cheesburgh, 1982) and sub cultured unto nutrient broth for $24 \mathrm{~h}$ prior to testing.

\subsection{Antimicrobial screening}

The PEE, BE, ME, and WE extracts (100mg) were dissolved in $1 \mathrm{ml}$ of (DMSO, Merck, Germany) and diluted to a final concentration of $20 \mathrm{mg} / \mathrm{ml}$; other concentrations were made $(15,10$ and $5 \mathrm{mg} / \mathrm{ml})$ by serial dilutions. The solutions were sterilized by filtration through a $0.45 \mu \mathrm{m}$ membrane filter. Sterile $9 \mathrm{~mm}$ discs were impregnated with $50 \mu \mathrm{l}$ of extract and placed on the surface of agar plates inoculated with a microbial culture. Each extract was tested in triplicate. Ciprofloxacin $(40 \mu \mathrm{g} / \mathrm{disc})$ served as positive control for the bacteria, whereas amphotericin B $(25 \mu \mathrm{g} / \mathrm{disc})$ was control for C. albicans. The plates were incubated at $37^{0} \mathrm{C}$ for 24 hours. Antimicrobial activity was recorded if the zone of inhibition was greater than $9 \mathrm{~mm}$.

\subsection{Statistics}

One way analysis of variance (ANOVA) was used to test for level of significance.

\section{Results}

The results of phytochemical screening of stem bark solvent extracts of $X$. americana are presented in Table 1 . The three solvent extracts revealed the presence of flavonoids, saponins, tannins and terpenoids. However, alkaloids, pylobatanins and cardiac glycosides were absent in the water extracts. The antimicrobial screening of the extracts showed that the activity of methanolic and water extracts appeared to be more significant $(\mathrm{P}<0.05)$ broad spectrum effect against the growth of E.coli, P. auruginosa, P. vulgaris, S. aureus and B.subtilis than the butanolic extract at 10, 15 and $20 \mathrm{mg} / \mathrm{ml}$ concentrations. The results indicate that the organisms were susceptible at higher concentration of the extract $(20 \mathrm{mg} / \mathrm{ml})$. The extract also showed some activity against C.albicans at $20 \mathrm{mg} / \mathrm{ml}$ while ciprofloxacin the standard drug for bacteria, failed to inhibit the growth of $C$. albicans. In general the bacteria were found to be more sensitive to the extract.

\section{Discussion}

Microbial infection involving microorganism's poses a very serious public health problem all over the world especially in resource poor African countries. To provide scientific support on the use of $X$. americana traditionally in the treatment of infections we tested the different solvent extracts on some common pathogenic organisms. Extracts of $X$. americana which was tested for antibacterial activity was found to have broad spectrum effect on the growth of many of the test organisms, E. coli, and P. vulgaris, S.aureus, P. aeruginosa and B. subtilis). The results tend to agree with similar work (Msonthi, 1986; Vlietinck et al., 1995; Akiniyi et al., 1996; Ogunleye and Ibitoye, 2003; Rabe and Van Staden, 1997; Buwa and Stada, 2006; Mohanasundari et al., 2007).

The reasons for the differential sensitivity pattern between gram-positive and gram- negative bacterial strains could be due to the outer phospholipids membrane with the structural lipopolysaccaride components, which make their cell wall impenetrable to antimicrobial agents (Nikaido and Va'ara, 1985), while the gram positive bacteria is more susceptible having only an outer peptidogycan, which is not an effective permeability barrier (Scherer and Gerhardt, 1971). Ximenia americana exerted more broad spectrum inhibitory activity against the microorganisms. Our results showed that there was some little activity of the extract on C. albicans, a fungus at a higher concentration. This also tends to agree with similar work (Balakrishna et. al., 2000) who reported that alcoholic extracts of Solanum trilobatum were effective on fungi at higher concentrations. Though the extract concentration was high $(20 \mathrm{mg} / \mathrm{ml})$ when compared to the concentration of the antibiotic (Ciproflaxicin) which was $40 \mu \mathrm{g}$. This could be explained that the extracts were still in 
their crude form made of complex composition of chemicals compared to the standard drug which was a pure compound. Further purification of the extracts could lead to isolation of purer compounds with increased microbial activity. The medicinal value of plants lies in some chemical substances produced by these plants, these chemicals called "secondary metabolites" include; alkaloids, flavonoids, tannins and phenolic compounds (Cowan, 1999). The mechanisms of action of the chemical constituents of the extracts are difficult to speculate at this point, however, it is known that many antibacterial agents exhibit their actions either by inhibiting the synthesis of the cell wall, nucleic acid, or blocking the synthesis of proteins. Flavonoids have been reported (Dixon et al., 1983; Hostettman et al., 1995; Tsuchiya et. al., 1996) to complex with extracellular and soluble proteins and to complex with bacterial cell walls. Tannins have the ability to inactivate microbial adhesions,enzymes, cell envelope transport proteins and also complex with polysaccharide (Ya et. al., 1988; Scalbert, 1991). Terpenoids have also been (Tassou et al., 1995; Taylor et al., 1996) reported to be active against bacteria, the mechanism of action involve membrane disruption by the lipophilic compounds. The results of the present study support the use of X. americana as having antibacterial properties that can be used as agent in new drugs for the therapy of infectious diseases caused by pathogens. The phytochemicals can further be isolated and undergo further pharmacological evaluation.

\subsection{Conclusion}

This study justifies the claimed uses of the $X$. americana in the traditional system of managing various infections diseases caused by microorganisms. The herbalists simply use water as the medium of extracting the active principles.

\section{Acknowledgement}

This work was sponsored in part by Carnegie and Ahmadu Bello University, Zaria, Nigeria. We are indeed grateful to them.

\section{References}

Akinniyi, J.A., Manawadu, D., Sultanbawa, M. (1996). Ethnobotany and Ethnopharmacology of Nigerian medicinal Plants Research in Nigeria. p. 35-349.

Arbonnier, M. (2004). Trees, Shrubs and lianas of West African dry zones. Margraf Publishers CIRAD GMBH, MNHN.

Balakrishna, K., Veluchamy, G., Ragothanan, P., Sajan, G. (2000). Antimicrobial activity of S. trilobatum. Proceedings of International congress on Ayurveda 2000. Chennai. Tamil Nadu, India. p 211.

Buwa, L.V., Staden, J.V. (2006). Antibacterial and antifungal activity of traditional medicinal plants used against venereal diseases in South Africa. Journal of Ethnopharmacology, 103:139-142.

Cheesbrough,M. (1982). Medical Laboratory Manual for Tropical countries. Microbiology. English Language Book Service (ELBS). Vol. 11.pp 283-378.

Cowan, M.M. (1999). Plant products as antimicrobial agents. Clin. Microbiol. Rev., Vol. 12. (4):564-582.

Dixon, R.A.,Dey, P.M., Lamb, C.J. (1983). Phytoalexins: enzymology and molecular biology. Adv. Enzymol. 55: 1-69.

Harborne, J.B. (1973). Phytochemical methods. London Chapman and Hall Ltd. p.49-188.

Hostettman, K., Marston, A.J., Wolfender, L., Miallard, M. (1995). Screening for flavonoids and related compounds in medicinal plants by LC-UV-MS and subsequent isolation of bioactive compounds. Akademiiai, Kiaho: Budapest, pp. $35-52$.

Hugo, W.B., Russel, A.D. (1983). Pharmaceutical Microbiology. $3^{\text {rd }}$ Edition Blackwell Scientific publication. p. 167.

Latte K.P. (1999). Phytochemische und pharmakologishe untersuctunger an Pelargonium reniforme curt. PhD thesis, University of Berlin.

Maikai V.A., Nok A.J., Adaudi A.O., Alawa C. (2008). In vitro antitrypanosomal activity of aqueous and methanolic crude extracts of stem bark of Ximenia americana on Trypanosoma congolense. Africa Journal of Biotechnology, vol.2 (3): 055-058.

Mohanasundari, C., Natarajan, D., Srinivasan, K., Umamaheswari, S., Ramachandran, A. (2007). Antibacterial properties of Passiflora foetida L. a common exotic medicinal plant. African Journal of Biotechnology, Vol. 6 (23): 2650-2653.

Msonthi, J.D. (1986). The status of medicinal plant research and traditional medicine in malaria. In: The state of medicinal plants research in Nigeria. P. 335-349.

Namikawa, I. (1996). Comparative study on the antibacterial activity of phytochemical flavonones against methicillin-resistant Staphylococcus aureus. J. Ethnopharmacol. 50:27-34. 
Nikaido, H., Vaara, M. (1985). Molecular basis of bacterial outer membrane permeability. Microbiological Review.1:1-32.

Ogunleye, D.S. and Ibitoye, S.F. (2003). Studies of antimicrobial activity and chemical constituents of Ximenia americana. Tropical Journal Pharmacology Research, Vol. 2, No. 2, pp 239- 241.

Rabe, T., Van Staden, J. (1997). Antibacterial activity of South African plants used for medicinal purposes. J. Ethnopharmacology, 56:81-87

Scalbert, A. (1991). Antimicrobial properties of tannins. Phytochemistry, 30:3875-3883.

Scherer, R., Gerhardt, P. (1971). Molecular sieving by the bacillus megaterium cell wall and protoplast. Journal of Bacteriology, 107:718-735.

Sofowora, A. (1993). Medicinal plants and Traditional Medicine in Africa. Spectrum Books Ltd, Ibadan, Nigeria. p. 289 .

Tassou, C.C., Drosinos, E.H., Nychas, G.J.E. (1995). Effects of essential oil from mint (Mentha piperita) on Salmonella enteitidis and Listeria monocytogenes in model Food systems at $4^{\circ}$ and 10 ${ }^{\circ} \mathrm{C}$. J. Appl. Bacteriol, 78:593-600.

Taylor, R.S.L, Edet, F., Manandhar, N.P., Towers, G.H.N. (1996). Antimicrobial activities of southern Nepalase medicinal plants. J. Ethnopharmacol, 50:97-102.

Trease, G.E., Evans, W.C. (1989). Pharmacognosy. $11^{\text {th }}$ Edition Brailliar Trindel Can. Macmillan Publishers.

Tsuchiya, H., Sato, M., Linuma, M., Yokoyama, J., Ohyama, M., Tanaka, T., Takase, I., Vlietinck, A.J., Vanhoof, L., Totte, J., Lasure, A., Vandenberge, D., Rwangabo, P.C., Mvukiyumwami, J. (1995). Screening of hundred Rwandese medicinal plants for antimicrobial and antiviral properties. Journal of Ethnopharmacology, 46:31-47.

Ya, C., Gaffney, S.H., Lilley, T.H., Haslam, E. (1988). Carbohydrate-polyphenol complexation, p. 553. in R.W. Heminway and J.J Karchesy (ed). Chemistry and significance of condensed tannins. P lenum Press, New York, N.Y.

Table 1. Phytochemical screening of stem bark extracts of $X$. americana

\begin{tabular}{|c|c|c|c|c|c|c|c|c|}
\hline Extract & Alkaloids & Anthraquinones & $\begin{array}{l}\text { Cardiac } \\
\text { glycosides }\end{array}$ & Flavonoids & Pylobatannins & Saponnins & Tannins & Terpenoids \\
\hline $\begin{array}{l}\text { Butanol } \\
\text { extract } \\
(\mathrm{BE})\end{array}$ & + & - & + & ++ & + & ++ & ++ & ++ \\
\hline $\begin{array}{l}\text { Methanolic } \\
\text { extract } \\
(\mathrm{ME})\end{array}$ & ++ & + & ++ & ++ & ++ & +++ & +++ & +++ \\
\hline $\begin{array}{l}\text { water } \\
\text { extract } \\
(\mathrm{WE})\end{array}$ & - & + & - & +++ & - & ++ & ++ & ++ \\
\hline
\end{tabular}

+++ - highly present, $\quad++$ - moderately present, + - faintly present, - absent 
Table 2. Antimicrobial activity of stem bark extracts of $X$. americana

\begin{tabular}{|c|c|c|c|c|c|c|c|}
\hline \multirow[t]{2}{*}{ Extract/drug } & \multirow{2}{*}{$\begin{array}{l}\text { Extract } \\
\text { conc. } \\
(\mathrm{mg} / \mathrm{ml})\end{array}$} & \multicolumn{6}{|c|}{ Zone of inhibition (mm) } \\
\hline & & $\begin{array}{l}\text { Escherichia } \\
\text { coli }\end{array}$ & $\begin{array}{l}\text { Pseudomon } \\
\text { as } \\
\text { aeruginosa }\end{array}$ & $\begin{array}{l}\text { Proteus } \\
\text { vulgaris }\end{array}$ & $\begin{array}{l}\text { Staphylococc } \\
\text { us aureus }\end{array}$ & $\begin{array}{l}\text { Candia } \\
\text { albicans }\end{array}$ & $\begin{array}{l}\text { Bacillus } \\
\text { subilis }\end{array}$ \\
\hline \multirow{5}{*}{$\begin{array}{l}\text { Butanol } \\
\text { extract (BE) }\end{array}$} & & & & & & & \\
\hline & 5 & - & - & - & - & - & - \\
\hline & 10 & - & - & - & - & - & - \\
\hline & 15 & - & 10 & 5 & 8 & - & 10 \\
\hline & 20 & 7 & 12 & 7 & 11 & - & 14 \\
\hline \multirow{5}{*}{$\begin{array}{l}\text { Methanol } \\
\text { extract (ME) }\end{array}$} & 5 & - & - & - & - & - & - \\
\hline & 10 & 6 & 10 & 11 & 9 & - & 8 \\
\hline & 15 & 10 & 15 & 15 & 13 & - & 9 \\
\hline & 20 & 18 & 17 & 18 & 15 & 8 & 14 \\
\hline & 5 & - & - & - & - & - & - \\
\hline \multirow{4}{*}{$\begin{array}{l}\text { Water } \\
\text { extract (WE) }\end{array}$} & 10 & 9 & 7 & 10 & 8 & - & 10 \\
\hline & 15 & 14 & 12 & 14 & 14 & - & 13 \\
\hline & 20 & 19 & 17 & 19 & 20 & 12 & 19 \\
\hline & $40 \mu \mathrm{g} / \mathrm{disc}$ & 37 & 40 & 38 & 38 & 0 & 40 \\
\hline
\end{tabular}

\begin{tabular}{llllllll}
\hline Ciprofloxaci & & & & & & \\
$\mathrm{n}$ & $25 \mu \mathrm{g} / \mathrm{disc}$ & 0 & 0 & 0 & 0 & 28 & 0
\end{tabular}

\begin{tabular}{l}
\hline Amphoterici \\
$\mathrm{n}$ \\
\hline - no activity \\
Values greater than $9 \mathrm{~mm}$ indicate activity
\end{tabular}

